\title{
Vibration associated with cryotherapy to relieve pain in children
}

\author{
Vibração associada à crioterapia no alívio da dor em crianças
}

José Marden Mendes-Neto', Sandra Lauton Santos ${ }^{1}$

DOI 10.5935/2595-0118.20200012

\section{ABSTRACT}

BACKGROUND AND OBJECTIVES: The administration of intramuscular drugs and peripheral venous puncture are procedures that use needles cause pain, especially in children. This painful experience generates distress, phobia, tachycardia, refusal to further treatments, anxiety, and sadness in parents. The use of non-pharmacological methods such as vibration and cold for pain relief in children has become a reliable alternative. The objective of this study was to evaluate the association between vibration and cryotherapy as a strategy for the relief of pain in children undergoing procedures with the use of needles.

CONTENTS: This is an integrative review, in which articles were searched in the Pubmed, Medline, BDENF and LILACS databases, using the descriptors: "Child", "Vibration", "Cryotherapy" and "Pain" associated with the Boolean operator "and". After the selection and reading of the articles in full, they were systematically synthesized and classified with a level of scientific evidence 2 . Studies have shown that the association between vibration and cryotherapy is effective in reducing pain in children with or without cognitive alterations, also reducing their and parents' anxiety during procedures performed with needles.

CONCLUSION: The implementation of vibration associated with cryotherapy during the administration of injectable drugs and the installation of a peripheral venous device can reduce the fear, anguish, and anxiety in children, calming the parents and benefiting health professionals.

Keywords: Child, Cryotherapy and pain, Vibration.

\section{RESUMO}

JUSTIFICATIVA E OBJETIVOS: A administração de fármacos por via muscular e a punção venosa periférica são procedimentos que utilizam agulhas e causam dor, especialmente em crianças. Essa experiência dolorosa gera angústia, fobia, taquicardia, recusa em tratamentos posteriores, além da ansiedade e desconforto na família. A utilização de métodos não farmacológicos, como a vibração e a crioterapia para o alívio da dor em crianças tem se tornado uma forte alternativa. O objetivo deste estudo foi avaliar a utilização da associação entre a vibração e a crioterapia como estratégia para o alívio da dor em crianças submetidas a procedimentos com a utilização de agulhas.

CONTEÚDO: Trata-se de uma revisão integrativa, na qual, buscou-se artigos nas bases de dados: Pubmed, Medline, BDENF e LILACS, com a utilização dos descritores: "Criança", "Vibração", "Crioterapia" e "Dor" associados entre si com o operador booleano "and". Após a seleção e leitura dos artigos na íntegra, os mesmos foram sistematicamente sintetizados e classificados com nível de evidência científica 2. Os estudos demonstraram que a associação entre a vibração e a crioterapia apresentou eficácia na redução da dor em crianças com ou sem alteraçóes cognitivas, além de reduzir a ansiedade das crianças e dos pais durante os procedimentos executados com agulhas.

CONCLUSÃO: A implementação da vibração associada à crioterapia na administração de fármacos injetáveis ou na instalação de dispositivo venoso periférico, pode reduzir o medo, a angústia e a ansiedade nas crianças, tranquilizando os pais e beneficiando os profissionais de saúde.

Descritores: Criança, Crioterapia e dor, Vibração.

\section{INTRODUCTION}

Pain is defined as an unpleasant human experience related to the activation of the somatosensory nervous system after the occurrence of a real or potential injury ${ }^{1}$. Invasive procedures that use needles, such as peripheral venipuncture and injection of drugs, including immunobiologicals, cause undesired psychological, physiological, and emotional effects on children, causing stress on family and health professionals ${ }^{2}$. Child compliance and family agreement with the treatment are potentially compromised due to the need for procedures that cause discomfort and pain ${ }^{3}$. The implementation of non-pharmacological measures to relieve the pain caused by needle procedures facilitates the continuity of treatment by the child due to the reduction of stress and distress in these patients ${ }^{4}$. 
The use of vibration associated with low temperature (cryotherapy) as a non-pharmacological strategy to relieve the pain caused by needle procedures has been widely studied and is well accepted by the health team, the child and the family, as it decreases the occurrence of painful events, being easy to apply and considered a low-cost measure ${ }^{2,5}$.

The physiological mechanisms of pain relief provided by vibrating movements and cryotherapy are related to the sharing of synapses in the spinal cord. The nerve fibers conduction the pain stimulus shares the synaptic pathways with the thermal conduction fibers activated by thermoreceptors (temperature-sensitive) and with the mechanic conduction fibers, activated by mechanoreceptors (stimulated by the vibration). The interference of this interneuronal response inhibits the pain stimulus, causing relief ${ }^{60,7}$.

Studies have shown that the use of cryotherapy is effective in relieving the pain generated by the intravenous administration of botulinum toxin in patients with facial dystonia and women during labor ${ }^{8,9}$. Vibratory stimulation has been shown to be beneficial in relieving muscle pain caused by intense physical exercise and during intravenous administration of local anesthetics in patients ${ }^{10,11}$. Evidence points to the benefit of pain relief in children when combining vibration and cryotherapy in procedures using needles ${ }^{2,5}$.

The motivation of the present study arose from the perception of a gap in critical reflections in the literature about the importance and effectiveness of cryotherapy associated with vibration as a non-pharmacological intervention to relieve pain, anxiety, and stress in children, caused by therapies that require the use of needles.

Therefore, this study aimed to evaluate the use of the association between vibration and cryotherapy as a strategy for pain relief in children undergoing procedures using needles.

\section{CONTENTS}

A bibliographic and descriptive study, characterized as an integrative review to identify and analyze, in scientific production, the use of vibration associated with cryotherapy to relieve pain in children. This study followed six methodological steps: 1 . Determination of the theme and selection of the research hypothesis or question for the construction of the integrative review; 2. Elaboration of criteria for the selection of studies/samples; 3 Definition of the information to be extracted from the selected studies and categorization of the studies; 4 Evaluation of included studies; 5 Interpretation of the results and 6 . Presentation of the review ${ }^{12}$.

This review was structured to answer the following guiding question: What is the effect of the association of vibration with cryotherapy to relieve pain in children undergoing needle procedures?

The literature search was performed in the Pubmed, Medline, BDENF (Nursing Database) and LILACS databases from November 2018 to March 2019, using the following controlled keywords: "Child", "Vibration", "Cryotherapy" and "Pain", as well as their English correspondents, interconnected by the Boolean operator "AND".
The inclusion criteria were published studies, with access to the full textual content that addressed the researched theme, papers with sample comprising children and adolescents (zero to 18 years old), and written in Portuguese, English, or Spanish. The exclusion criteria were review articles, experience reports, theses, dissertations, animal model studies and samples composed of adults. There were no restrictions based on year of publication.

After searching the databases, a total of 94 articles were found, which initially went through the selection and analysis steps in order to delineate the sample of the present review.

The publications were selected in four interrelated stages. During the first round, articles that were not available with full-textual content $(n=4)$ were excluded, and later, papers with duplicate databases $(n=11)$ were eliminated. In the second-to-last stage, studies that did not address the study objective after reading the title and abstract $(n=66)$ were excluded. Subsequently, the articles were carefully and critically read in their entirety using structured records in an adapted instrument, and, at this stage, five $(n=5)$ papers were excluded due to the use of dental procedures in adults 5 . The study selection flowchart is shown in figure 1 .

After selection, eight articles were included and coded in descending order of year of publication (N1 - N8) and systematically synthesized as to authors, year of publication, purpose, methods, strategies, and main results (Tables 1 and 2).

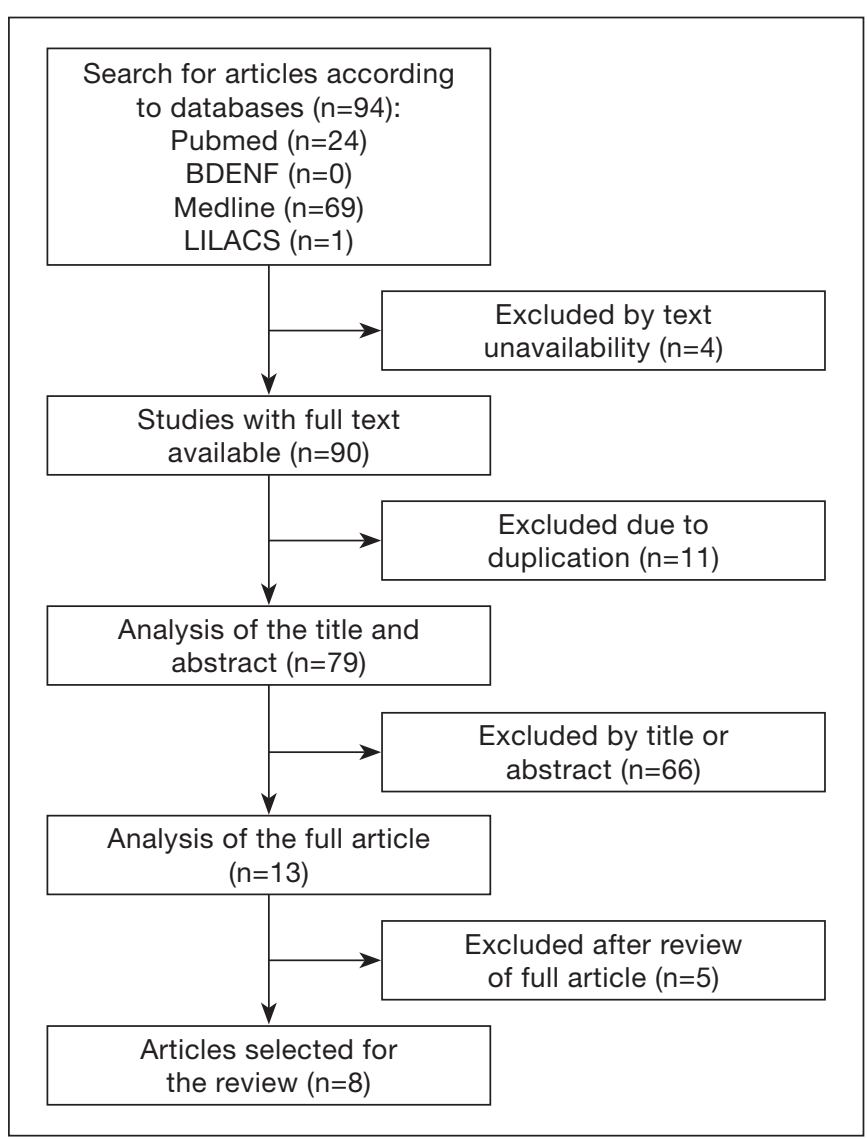

Figure 1. Selection of the studies 
Table 1. Summary of studies included in the review

\begin{tabular}{|c|c|c|c|}
\hline Code & Authors & Origin & Objectives \\
\hline $\mathrm{N} 1$ & $\begin{array}{l}\text { Bergomi et } \\
\text { al. }^{2}\end{array}$ & Italy & $\begin{array}{l}\text { Evaluation of vibration associated with cryothera- } \\
\text { py with or without the use of cartoons to relieve } \\
\text { pain in children undergoing venipuncture. } \\
\text { Evaluation of parents' anxiety regarding these pain } \\
\text { relief interventions. }\end{array}$ \\
\hline N2 & $\begin{array}{l}\text { Redfern, } \\
\text { Chen and } \\
\text { Sibrel }^{20}\end{array}$ & $\begin{array}{l}\text { United } \\
\text { States } \\
\text { States }\end{array}$ & $\begin{array}{l}\text { To determine if vibration associated with cryother- } \\
\text { apy was able to relieve pain in children undergoing } \\
\text { immunization. }\end{array}$ \\
\hline N3 & $\begin{array}{l}\text { Moadad et } \\
\text { al. }^{3}\end{array}$ & $\begin{array}{l}\text { United } \\
\text { States } \\
\text { States }\end{array}$ & $\begin{array}{l}\text { To investigate the use of vibration and cryotherapy } \\
\text { in pain relief during peripheral venous catheter in- } \\
\text { sertion in children. }\end{array}$ \\
\hline
\end{tabular}

N4 Schreiber Italy et al. ${ }^{21}$

To test the effectiveness of using cryotherapy associated with vibration to relieve the pain induced by peripheral venipuncture in children with cognitive impairment. Sahiner et al. ${ }^{14}$

To determine the effect of cryotherapy associated with vibration in relieving the pain and anxiety triggered by immunization against diphtheria, tetanus, and infections caused by pertussis in children.

Evaluation of the effect of cryotherapy associated with vibration on pain and anxiety in children undergoing peripheral venous catheter installation. Kelleci²3

To investigate the effect of cryotherapy associated with vibration to relieve the pain and reduce the anxiety in children during blood collection for laboratory tests.

N8

Baxter et United al. ${ }^{18}$ States States
Methods

150 binomials (5-12-year-old children and their parents) were randomly divided into four groups: 1 . control group, which did not undergo any pain relief intervention, 2. Buzzy ${ }^{\circledR}$ group, 3. Buzzy ${ }^{\circledR}$ group associated with drawing and 4 . cartoon group. All children underwent peripheral venipuncture.

Fifty children and adolescents (5-18 years old) were randomly divided into two groups: 1. group using Buzzy ${ }^{\circledR}$ and 2. group without the device, both submitted to immunization by intramuscular route.

48 dyads (children aged 4 to 12 years and their mothers) were randomly divided into two groups: 1 . control group (not exposed to Buzzy ${ }^{\circledR}$ ) and 2. group using Buzzy ${ }^{\circledR}$. Both groups were comprised children whose treatment required passing a peripheral venous catheter.

71 children with cognitive impairment were randomly allocated to two experimental groups: 1. control, in which they were not exposed to Buzzy ${ }^{\circledR}$ and group 2 children submitted to Buzzy ${ }^{\circledR}$. Both groups underwent peripheral venous device installation.

104 school-age children (up to 7 years old) were randomly divided into two groups by a computer program: 1. control group that was not exposed to Buzzy ${ }^{\circledR}$ and 2 . group that was subjected to Buzzy ${ }^{\circledR}$. The pain stimulus was established by the administration of the vaccine (DTP) to the deltoid muscle, $5 \mathrm{~cm}$ above the site of the Buzzy ${ }^{\circledR}$ device.

176 children aged 7 to 12 years were randomly divided into two groups using a computer program: a control group, which was not exposed to Buzzy ${ }^{\circledR}$, and the group with Buzzy ${ }^{\circledR}, 5 \mathrm{~cm}$ above the peripheral venipuncture site.

120 children from 6 to 12 years of age were randomly divided into two groups: 1 control group that was not stimulated with Buzzy ${ }^{\circledR}$ and group 2, with children submitted to Buzzy ${ }^{\circledR}$, both groups underwent the installation of a venous catheter to collect blood.

81 children and adolescents aged 4 to 18 years were randomly divided into two experimental groups: 1 . control group, which was not stimulated with Buzzy ${ }^{\circledR}$ and 2. group exposed to Buzzy ${ }^{\circledR}$. Both underwent the installation of a peripheral venous catheter to collect blood.

Table 2. Summary of strategies and main results of the studies

\begin{tabular}{|c|c|c|}
\hline Code & Strategies & Main results \\
\hline N1 & $\begin{array}{l}\text { The vibration associated with cryotherapy was induced by the Buzzy }{ }^{\circledR} \text { device, } \\
\text { whether or not associated with the cartoon. } \\
\text { The perception of pain in children was assessed by the Wong-Baker faces } \\
\text { scale, which was also used by nurses who performed the procedure. } \\
\text { The nurses also assessed the pain in children using the emotional manifesta- } \\
\text { tion scale. } \\
\text { Parents' anxiety was assessed using the numerical scale from zero to } 10 \text {. }\end{array}$ & $\begin{array}{l}\text { The vibration associated with cold and cartoons } \\
\text { minimized the pain in children submitted to ve- } \\
\text { nipuncture. These pain control interventions also } \\
\text { contributed to reducing parents' anxiety. }\end{array}$ \\
\hline N2 & $\begin{array}{l}\text { Vibrating stimulation and cryotherapy were established by Buzzy }{ }^{\circledR} \text {. } \\
\text { The pain was measured in the groups using the Wong-Baker faces scale, and a } \\
\text { modification of this scale allowed the assessment of children's anxiety. } \\
\text { Parents' satisfaction was investigated based on the experience with the study } \\
\text { by applying a questionnaire and assigning a score that ranged from poor to } \\
\text { excellent. }\end{array}$ & $\begin{array}{l}\text { Anxiety showed no difference between the } \\
\text { groups. } \\
\text { The pain was much lower in the vibration and cold } \\
\text { group compared to the control group. } \\
\text { There was no statistical difference in the as- } \\
\text { sessment of parents' satisfaction between the } \\
\text { groups. }\end{array}$ \\
\hline
\end{tabular}


Table 2. Summary of strategies and main results of the studies - continuation

\begin{tabular}{|c|c|c|}
\hline Code & Strategies & Main results \\
\hline N3 & $\begin{array}{l}\text { The pain stimulus was established by peripheral venipuncture. And thermal } \\
\text { (cryotherapy) and vibration stimulation were promoted by the Buzzy }{ }^{\circledR} \text { device. } \\
\text { Pain assessment in children occurred by applying the Wong-Baker faces scale } \\
\text { by researchers, parents, and the nurse who installed the peripheral device. The- } \\
\text { se answers were compared. }\end{array}$ & $\begin{array}{l}\text { Vibration associated with cryotherapy was effec- } \\
\text { tive in reducing pain in children undergoing peri- } \\
\text { pheral venous device insertion. } \\
\text { The researchers, nurses, and parents' assess- } \\
\text { ment was similar in attesting pain relief in these } \\
\text { children. }\end{array}$ \\
\hline N4 & $\begin{array}{l}\text { The pain was induced by the installation of a peripheral venous catheter, and } \\
\text { the Buzzy }{ }^{\circledR} \text { device was used to cause the vibration associated with cryotherapy. } \\
\text { Pain assessment was measured using the pain verification scale in non-com- } \\
\text { municative children, surgery version. }\end{array}$ & $\begin{array}{l}\text { Children who received vibration associated with } \\
\text { cryotherapy showed a reduction in pain in the pe- } \\
\text { ripheral venous catheter installation. }\end{array}$ \\
\hline N5 & $\begin{array}{l}\text { The pain was promoted by intramuscular vaccine administration and the vibra- } \\
\text { tion stimulation associated with cryotherapy was provided by the Buzzy }{ }^{\circledR} \text { device } \\
\text { in both groups. } \\
\text { Each child was assessed for pain by two examiners: one nurse who applied } \\
\text { the vaccine and one researcher using the Wong-Baker faces scale and verbal } \\
\text { pain report. } \\
\text { Anxiety was assessed using the child's fear scale. }\end{array}$ & $\begin{array}{l}\text { The association of the vibration stimulation and } \\
\text { cryotherapy was effective in reducing pain and } \\
\text { anxiety in children undergoing immunization } \\
\text { against diphtheria, tetanus, and infections caused } \\
\text { by pertussis. }\end{array}$ \\
\hline N6 & $\begin{array}{l}\text { The Buzzy }{ }^{\circledR} \text { device was used for vibration stimulation associated with cold. } \\
\text { Pain stimulation and anxiety were stimulated by the insertion of a peripheral } \\
\text { venous catheter. } \\
\text { Pain assessment was conducted using the Wong-Baker faces scale and the } \\
\text { visual analog scale. } \\
\text { The child's anxiety was assessed by their parents based on behavioral and } \\
\text { verbal analysis. }\end{array}$ & $\begin{array}{l}\text { The application of cryotherapy associated with } \\
\text { vibration is effective in reducing the pain and an- } \\
\text { xiety in children, generated by the venipuncture } \\
\text { necessary to pass a peripheral venous catheter. }\end{array}$ \\
\hline N7 & $\begin{array}{l}\text { The vibration stimulus associated with cryotherapy was given with the Buzzy } \\
\text { device, } 5 \mathrm{~cm} \text { above the puncture site throughout the procedure. } \\
\text { Anxiety and pain were assessed by the anxiety and pain scales, as well as by } \\
\text { the revised faces scale applied by the researchers. }\end{array}$ & $\begin{array}{l}\text { The group using the Buzzy }{ }^{\circledR} \text { device showed re- } \\
\text { duced anxiety and pain compared with the con- } \\
\text { trol group. }\end{array}$ \\
\hline N8 & $\begin{array}{l}\text { Buzzy }{ }^{\circledR} \text { was the device used for vibration stimulation associated with cryother- } \\
\text { apy, placed } 5 \mathrm{~cm} \text { above the puncture site. } \\
\text { Anxiety and pain were assessed by the anxiety and pain scales for children, } \\
\text { both applied by the researchers. }\end{array}$ & $\begin{array}{l}\text { Low temperature associated with vibration redu- } \\
\text { ced the pain in children and adolescents under- } \\
\text { going peripheral venipuncture compared to the } \\
\text { control group that received no stimulation. }\end{array}$ \\
\hline
\end{tabular}

All studies were in English, developed in the following countries: United States $(n=3)$, Turkey $(n=3)$, Italy $(n=2)$, and classified as level 2 of scientific evidence ${ }^{13}$. All studies used the cryotherapy associated with the vibration device, Buzzy ; which has the shape of a bee, whose body emits vibratory waves, and the wings are cooled to reduce the local temperature. The device was placed $5 \mathrm{~cm}$ from the site of the needle insertion $^{2,5}$

\section{DISCUSSION}

Needle procedures are the main causes of pain in children, especially in the age group from 5 to 10 years of age, and trigger behavioral, psychological, physiological and emotional changes that have a major impact on health, such as phobia, anxiety, tachycardia, sadness, and hormonal changes. Such events may compromise the drug therapy in these patients, especially the child's resistance to future treatments, as well as the anxiety of the family and health professionals ${ }^{3,14}$. The implementation of pain relief measures in children undergoing needle procedures is important and increasingly necessary, as it promotes the child and family compliance with subsequent treatments, reduces fear, and reframes the meaning of care. Pain relief can be achieved with the use of pharmacological measures that favor the reduction of pain perception with the use of drugs or with non-pharmacological measures, which are widely studied in children ${ }^{15,16}$.

Many non-pharmacological pain relief strategies are effective during the clinical management of hospitalized children, among them the use of therapeutic toys, the use of cartoon, non-nutritive sucking, and especially the association of vibration with cryotherapy ${ }^{15,17}$.

The effectiveness of vibration and cryotherapy in reducing pain is related to the blockage of the afferent receptive nerve fibers to pain stimuli (A-delta and $C$ fibers) and also to the stimulation of the non-nociceptive A-beta fibers, which activate the inhibitory interneurons reducing the conduction of the pain information to the spinal cord in the central nervous system ${ }^{18,19}$. All studies (N1-N8) showed that the association of vibration with cryotherapy reduced the pain related to the use of needles during treatment in children. In addition, studies (N5, N6, and N7) also reported a reduction in the child's anxiety during the procedure, which did not occur in study N2, which also evaluated anxiety during the procedure in these patients ${ }^{2,3,14,18,20-23}$.

Most studies (N1, N3, N5, N6, N7, and N8) used the Wong-Baker faces scale to assess the pain in children in different groups. Only one study modified this scale $(\mathrm{N} 2)^{20}$, which 
adapted it to analyze the anxiety level in addition to pain in children. Study $\mathrm{N}^{21}$ was the only study developed with children with cognitive impairment. Pain assessment in these children was performed using the pain verification scale in non-communicative children, in the surgery version ${ }^{2,3,14,18,22,23}$. Other pain assessment scales were used in association with the Wong-Baker faces scale. In study $\mathrm{N}^{2}$, nurses assessed pain in children through the emotional manifestation scale; study $\mathrm{N} 6$ used the visual analog scale, and studies $\mathrm{N} 7^{23}$ and $\mathrm{N} 8^{18}$ used the anxiety and pain scale. Study $\mathrm{N} 5^{14}$ assessed the pain stimulus by the child's verbal report.

Two studies investigated parent-related aspects of the participating children. $\mathrm{N}^{2}$ assessed parents' anxiety using a numerical scale ranging from zero to 10 and found that the parents' anxiety was lower in the group of children with the Buzzy" device. Study N2 $2^{20}$ assessed parents' satisfaction using a structured questionnaire, but there was no difference between the groups of children with or without the device.

Family engagement is important and should be encouraged and implemented during the application of pain relief techniques in children, since family bonding is one of the main factors contributing to the child's comfort and stress reduction, facilitating the professional's job ${ }^{16}$.

\section{CONCLUSION}

The use of non-pharmacological measures for pain relief in children is a strategy well accepted by health professionals and parents when the child undergoes procedures that cause distress and pain. It was evident that vibration associated with cryotherapy reduced the pain and anxiety in children, with or without cognitive impairment, undergoing interventions that require the use of needles, and this fact explains the reduction of parents' anxiety and the satisfaction of the health professionals.

\section{REFERENCES}

1. IASP. Classification of Chronic Pain. $2^{\text {nd }}$ ed. Merskey H, Bogduk N, editors. IASP Pain Terminology. Seattle: IASP Press; 1994. 240p.
2. Bergomi P, Scudeller L, Pintaldi S, Dal Molin A. Efficacy of non-pharmacological methods of pain management in children undergoing venipuncture in a pediatric outpatient clinic: a randomized controlled trial of audiovisual distraction and external cold and vibration. J Pediatr Nurs. 2018;9(42):e66-72.

3. Moadad N, Kozman K, Shahine R, Ohanian S, Badr LK. Distraction using the BUZZY for children during an IV insertion. J Pediatr Nurs. 2016;31(1):64-72

4. McMurtry CM, Pillai Riddell R, Taddio A, Racine N, Asmundson GJ, Noel M, et al Far from "Just a Poke": common painful needle procedures and the development of needle fear. Clin J Pain. 2015;31(10 Suppl):S3-11.

5. Ballard A, Khadra C, Adler S, Doyon-Trottier E, Le May S. Efficacy of the Buzzy device for pain management of children during needle-related procedures: a systematic review protocol. Syst Rev. 2018;7(1):78.

6. Kakigi R, Shibasaki H. Mechanisms of pain relief by vibration and movement. J Neurol Neurosurg Psychiatry. 1992;55(1):282-6.

7. Nahra H, Plaghki L. Innocuous skin cooling modulates perception and neurophysiological correlates of brief CO2 laser stimuli in humans. Eur J Pain. 2005;9(1):521-30.

8. Monteiro PB, Fonseca-Júnior NL, Rehder JR. Eficácia do resfriamento da pele no alívio da dor desencadeada pela injeçáo de toxina botulínica tipo A nas distonias faciais. Rev Bras Oftalmol. 2012;71(6):364-7.

9. Nunes $S$, Vargens OM. A crioterapia como estratégia no alívio da dor no trabalho de parto: um estudo exploratório. Rev Enferm UERJ. 2007;15(3):337-42.

10. Cochrane DJ. Effectiveness of using wearable vibration therapy to alleviate muscle soreness. Eur J Appl Physiol. 2017;117(3):501-9.

11. Fix WC, Chiesa-Fuxench ZC, Shin T, Etzkorn J, Howe N, Miller CJ, et al. Use of a vibrating kinetic anesthesia device reduces the pain of lidocaine injections: a randomized split-body trial. J Am Acad Dermatol. 2019;80(1):58-9.

12. Mendes KDS, Silveira RCCP, Galvão CM. Revisão integrativa: método de pesquisa para a incorporaçáo de evidências na saúde e na enfermagem. Texto Contexto Enferm. 2008;17(4):758-64.

13. Galvão CM. Níveis de evidência. (Editorial). Acta Paul Enferm. 2006;19(2):V.

14. Canbulat Sahiner N, İnal S, Sevim Akbay A. The effect of combined stimulation of external cold and vibration during immunization on pain and anxiety levels in children. J Perianesth Nurs. 2015;30(3):228-35.

15. Tan GX, Tunkel DE. Control of pain after tonsillectomy in children: a review. JAMA Otolaryngol Head Neck Surg. 2017;143(9):937-42.

16. Silva LD, Tacla MT, Rossetto EG. Manejo da dor pós-operatória na visăo dos pais da criança hospitalizada. Esc Anna Nery. 2010;14(3):519-26.

17. Virgens TR, Greco CSS, Carvalho ML. A influência da sucçấo náo nutritiva como analgesia năo farmacológica em recém-nascido durante procedimentos dolorosos: revisão sistemática. Rev Ciênc Méd. 2018;27(1):23-37.

18. Baxter AL, Cohen LL, McElvery HL, Lawson ML, von Baeyer CL. An integration of vibration and cold relieves venipuncture pain in a pediatric emergency department. Pediatr Emerg Care. 2011;27(12):1151-6.

19. Pakis Cetin S, Cevik K. Effects of vibration and cold application on pain and anxiety during intravenous catheterization. J Perianesth Nurs. 2019;34(4):701-9.

20. Redfern RE, Chen JT, Sibrel S. Effects of thermomechanical stimulation during vaccination on anxiety, pain, and satisfaction in pediatric patients: a randomized controlled trial. J Pediatr Nurs. 2018;38:1-7.

21. Schreiber S, Cozzi G, Rutigliano R, Assandro P, Tubaro M, Cortellazzo Wiel L, et al. Analgesia by cooling vibration during venipuncture in children with cognitive impairment. Acta Paediatr. 2016;105(1):e12-6.

22. Canbulat N, Ayhan F, Inal S. Effectiveness of external cold and vibration for procedural pain relief during peripheral intravenous cannulation in pediatric patients. Pain Manag Nurs. 2015;16(1):33-9.

23. Inal S, Kelleci M. Relief of pain during blood specimen collection in pediatric patients. MCN Am J Matern Child Nurs. 2012;37(5):339-45. 